\title{
INDUSTRIAL LEARNING THROUGH COURSE SEMINAR FOR FRESHMAN
}

\author{
Basanagouda Shivalli ${ }^{1}$, G R Chalageri ${ }^{2}$ \\ ${ }^{1,2}$ Department of Mechanical Engineering, \\ BVBCET-Hubballi \\ 1basangouda_s@bvb.edu \\ 2gireesha@bvb.edu
}

\begin{abstract}
The activity 'Industrial Learning' is carried out for first year students in the course 'Elements of Mechanical Engineering'. The Students were asked to work in the factory for one day and give seminar on the learning experiences. This innovative approach elicits interest of the students by giving exposure to work in the factory for one day. Students were thrilled about the fact that they were given an opportunity to seek employment at the industry. This approach made students to understand the expectations of industries in the first year of engineering itself by inculcating various exploratory learning attitudes like leadership, team work, time management and communication skills. In the due course of time students have come across many tools, products, devices, measuring equipments, jigs, fixtures and machineries. It has led a platform and basis for the students to visit various other industries in the future to expand the horizon of their knowledge on field of mechanical engineering that would hopefully be useful in their career. We got very good feedback from our stake holders i.e. students, parents and industries. It has resulted in improving their performance and understanding in the course.
\end{abstract}

Key words: EME, Exploratory learning attitudes, Stake Holders.

\section{Introduction}

Every human must work so as to fulfill his needs. In Sanskrit there is a saying as "udyogmpurushalakshanam" which actually means a person is characterized by the work he/she does. Thus it is evident how important working is. We all are aware that after completing our engineering most of us shall work in some or the other factory or industry. In most of the cases it is heard that there are lots of gaps between the techniques learnt in the college and the techniques applied in the factory [1]. It usually becomes difficult for a student to adapt himself to the techniques of the factory. So now, we are trying to bridge this gap by implementing the techniques like one day work in a factory in the course EME for first year students.

According to this project a student is supposed to visit a factory and work there for one day so that the student may be exposed to different elements of mechanical engineering. Usually in the previous academic semesters, group of students were asked to select any one mechanical object or concept and give a seminar on the same, but this time an attempt has been made to enhance the learning process of the students by exposing them to mechanical industries to work for one day. Here the students gave the course seminar from their learning experiences and submitted the project report. This approach will give practical, hands-on experience in understanding of the elements of mechanical engineering, like many tools, products, devices, measuring equipments, jigs, fixtures and machineries. Industrial Learning through Course seminar helps to enhance capacity of individuals to create a more fulfilled society [2]. The paper gives an insight on how the course seminar was conducted, details of rubrics used, evaluation criteria and its usefulness to students.

\section{Work done}

This part of the paper explains the method of conducting course seminar, its initial preparation and rubrics framed for evaluation purpose.
Basanagouda Shivalli

Department of Mechanical Engineering, BVBCET-Hubballi

basangouda_s@bvb.edu 
2.1 Preliminary preparation for conducting course seminar:

There are many mechanical industries in hubli, dharwad, belur and belgaum, where students can learn and collect information about mechanical elements for the seminar. The students were asked to work in any of the factory related to mechanical field and write a project report and also to present the same for the course seminar. The students were formed in group of four members each. They carried out the industry survey initially through various sources. Then they personally met with the employers of the firms and fixed their appointment of one day work (Refer Appendix 1). Totally 18 batches were formed consisting 4 students in a group.

\subsection{Contribution of the faculty member:}

The faculty member guided students on the importance of industries and helped each individual batch to contact the industries with request letter from the college. Once all groups were finalized, the faculty member framed proper rubrics for the course seminar. The rubrics consist of five important parameters. These rubrics were explained to students well in advance so that they can focus on these parameters while working and collecting the required information for the seminar. [3]

The faculty member conducted two hours class on how to work in a factory and importance of safety precautions to be taken in mechanical industries, also guided on the format of the project report for the convenience of the students as they were not exposed to it.

\subsection{Rubrics:}

Five different Parameters were used in the rubrics for measurement of effectiveness of the course seminar (Refer Table.1). [4]

All the parameters were measured for 15 marks each. If a particular performance parameter by the student or group presentation exceeds the expectation of the faculty then 14 to 15 marks will be allocated, if it meets the requirement then 12 to 13 marks based on the efforts made by the student, if it is progressing then 7 to 11 marks or if the work is below the expected level then the marks will be in the range of 1 to 6 .

Table 1. Rubrics followed for the Course seminar

\begin{tabular}{|c|c|c|c|c|}
\hline Marks & Exemplary (14-15) & Accomplished (12-13) & Developing (7-11) & Beginning (1-6) \\
\hline $\begin{array}{l}\text { Organization } \\
\& \text { structure }\end{array}$ & $\begin{array}{l}\text { All information } \\
\text { presented in logical, } \\
\text { interesting and } \\
\text { novel sequence and } \\
\text { is easy to follow. }\end{array}$ & $\begin{array}{l}\text { Most information is } \\
\text { presented in logical order } \\
\text { and is easy to follow. }\end{array}$ & $\begin{array}{l}\text { Difficult to follow } \\
\text { presentation due erratic } \\
\text { topical shifts and } \\
\text { jumps. }\end{array}$ & $\begin{array}{l}\text { Presentation lacks } \\
\text { structure. }\end{array}$ \\
\hline $\begin{array}{r}\text { Content } \\
\& \\
\text { Knowledge }\end{array}$ & $\begin{array}{l}\text { Demonstration of } \\
\text { full knowledge of } \\
\text { the subject with } \\
\text { explanations and } \\
\text { elaboration. }\end{array}$ & $\begin{array}{l}\text { At ease with content and } \\
\text { able to elaborate and } \\
\text { explain to some degree. }\end{array}$ & $\begin{array}{l}\text { Uncomfortable with } \\
\text { content. Capable of } \\
\text { only answering } \\
\text { rudimentary questions. }\end{array}$ & $\begin{array}{l}\text { No grasp of content. } \\
\text { Needs assistance } \\
\text { answering questions } \\
\text { about subject }\end{array}$ \\
\hline $\begin{array}{l}\text { Visual aids \& } \\
\text { neatness }\end{array}$ & $\begin{array}{l}\text { Text and } \\
\text { presentation are } \\
\text { reinforced by the } \\
\text { use of attractive } \\
\text { visual aids. } \\
\text { No spellings or } \\
\text { grammatical errors. }\end{array}$ & $\begin{array}{l}\text { Visual aids are adequate } \\
\text { and related to the text and } \\
\text { presentation. } \\
\text { Minor misspellings } \\
\text { and/or grammatical } \\
\text { errors. }\end{array}$ & $\begin{array}{l}\text { Poor quality of visual } \\
\text { aids or visual aids does } \\
\text { not support the text or } \\
\text { presentation. } \\
\text { Several spelling and/or } \\
\text { grammatical errors in } \\
\text { slides. }\end{array}$ & $\begin{array}{l}\text { No visual aids or } \\
\text { inadequate slides }\end{array}$ \\
\hline $\begin{array}{l}\text { Delivery \& } \\
\text { Speaking } \\
\text { skills }\end{array}$ & $\begin{array}{l}\text { Clear voice and } \\
\text { correct } \\
\text { pronunciation of } \\
\text { terms. } \\
\text { Good eye contact, } \\
\text { steady rate, } \\
\text { enthusiasm, or } \\
\text { confidence. }\end{array}$ & $\begin{array}{l}\text { Voice is clear and at a } \\
\text { proper level. Most words } \\
\text { pronounced correctly. } \\
\text { Some eye contact, steady } \\
\text { rate and adequately } \\
\text { rehearsed. }\end{array}$ & $\begin{array}{l}\text { Occasional } \\
\text { mispronunciation of } \\
\text { terms. Uses } \\
\text { appropriate } \\
\text { vocabulary. } \\
\text { Little eye contact, } \\
\text { uneven rate, or only } \\
\text { little expression. }\end{array}$ & $\begin{array}{l}\text { Mumbling or incorrect } \\
\text { pronunciation of terms. } \\
\text { Voice level too low or } \\
\text { too high. Does not use } \\
\text { appropriate } \\
\text { vocabulary. } \\
\text { Monotonous, no eye } \\
\text { contact, rate of speech } \\
\text { too fast or too slow. }\end{array}$ \\
\hline $\begin{array}{l}\text { Interaction } \\
\text { with } \\
\text { Audience }\end{array}$ & $\begin{array}{l}\text { Appearance is } \\
\text { professional. } \\
\text { Responds to } \\
\text { questions and } \\
\text { comments } \\
\text { confidently. }\end{array}$ & $\begin{array}{l}\text { Appearance is good. } \\
\text { Responds to questions } \\
\text { and comments well. }\end{array}$ & $\begin{array}{l}\text { Appearance marginally } \\
\text { acceptable. } \\
\text { Responds to questions } \\
\text { and comments, but is } \\
\text { not at ease or } \\
\text { confident. }\end{array}$ & $\begin{array}{l}\text { Inappropriate } \\
\text { appearance. } \\
\text { Needs assistance to } \\
\text { respond to questions } \\
\text { and comments. }\end{array}$ \\
\hline
\end{tabular}


Maximum marks: 15 (Total marks scored/5)

2.4 Students working in different industries

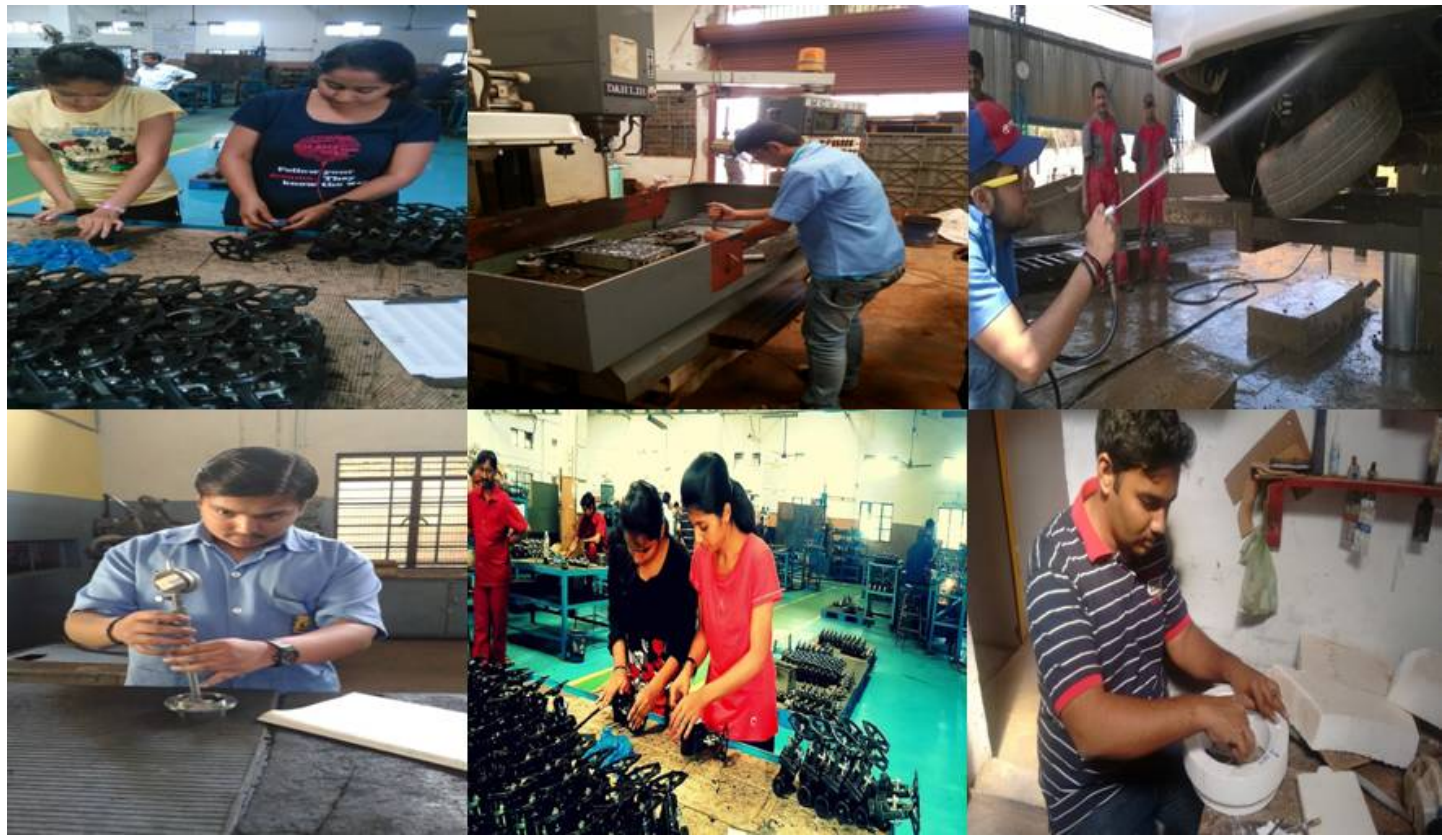

Fig. 1: Students working in different industries

\section{Conclusions}

The students of first year have been benefited in the following ways from course seminar.

- Now our students are able to analyse gap between the mechanical industries and syllabus of EME.

- The students were made to look for various different sources from where they can get relevant information on their work done at factories; hence students started getting familiarized to few important elements and processes of mechanical engineering.

- The students got exposed on how to write project report; it was like basic foundation for these students regarding technical reports. For the first time they made an attempt to write technical project reports.

- The course seminar helped students to gain extra knowledge about the subject apart from the syllabus and students were able to link the subject well with the seminar; hence the concepts of the subject were clear to them as they worked hard for the course seminar.

- Students came to know how Mechanical elements play an important role in today's world both in societal and industrial context.

- Each student had an opportunity to work in a team, collect the information, share it and present it to the class. Course seminar gave a chance to prove them a team player and improve communication skills.

- Our most esteemed stake holders (parents) are overwhelmed by seeing their ward's FIRST industry experience along with education.

\section{References}

1. Innovative Methods of Teaching, Dr. Damodharan V. S. ACCA, AICWA and Mr. Rengarajan.V AICWA.

2. Continuing Education and Local Support for Schools (CELSS) Resource Manual, Physical Activities for Classroom and Outdoors.

3. Jennifer M. Case , Gregory Light, 'Emerging Methodologies in Engineering Education Research' Journal of Engineering Education January 2011, Vol. 100, No. 1, pp. 186-210.

4. Vinayak Kulkarni et al., Measurement of Programme Outcome-h through Course Seminar, Journal of Engineering Education 


\section{APPENDIX I}

Following are the factories chosen by the students of 18 batches for the activity.

\begin{tabular}{|c|l|}
\hline Batch No & \multicolumn{1}{|c|}{ Name of the Factory } \\
\hline B1 & Advance Die Cast \\
\hline B2 & R.V Engineering Works \\
\hline B3 & Siddeshwar Pattern Works \\
\hline B4 & 2L Engg Works \\
\hline B5 & Ankush Industries \\
\hline B6 & Essvee Engg Works \\
\hline B7 & Flowserve Microfinish Pvt Ltd \\
\hline B8 & Karnatak Engineering Works \\
\hline B9 & Poly Valve Tech \\
\hline B10 & Pratiksha Engineering Works \\
\hline B11 & Quality Engineers \\
\hline B12 & Radha Cement Products \\
\hline B13 & Railway Carriage Repair Workshop \\
\hline B14 & Veetech Valves \\
\hline B15 & AIMS Pvt. Ltd \\
\hline B16 & Vijaya Engineering Works \\
\hline B17 & Shodha Toyota \\
\hline B18 & Siddheshwar Engg Works \\
\hline
\end{tabular}

